、 


\section{PREHISTORIC IRELAND}


45 


\section{PREHISTORIC IRELAND}

A MANUAL OF IRISH PRE-CHRISTIAN ARCHÆOLOGY

BY

REV. P. POWER, M.R.I.A.

Professor of Archaology, University College, Cork

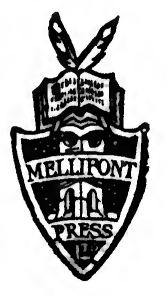

MELLIFONT PRESS, LTD. KILDARE HOUSE, WESTMORELAND STREET, DUBLIN 
Cahill \& Co., Ltd., Dublin, Drogheda, and London.
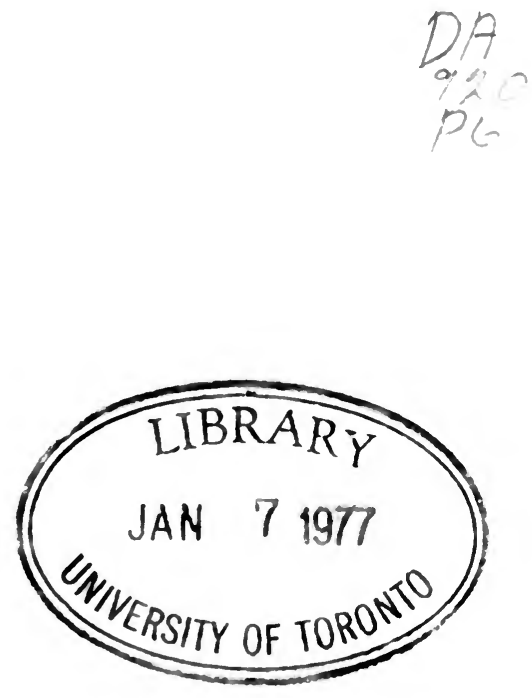


\section{PREFACE}

Although a full understanding of Irish history is impossible without some study of our national antiquities, it must be admitted that the latter is a sadly. neglected subject. For long Irish Archæology had in fact been left to charlatans and dabblers, whence it acquired a rather dubious reputation which, to a certain extent, perhaps adheres to it still. The time is, however, at hand, if indeed it has not already come, when Irish Archæology can be no longer ignored in Ireland, and when no Irishman who claims to be educated can afford to be ignorant of his country's ancient monuments. In some form the subject must find its way even into the secondary and, probably, into the primary school.

The present Manual, which makes no pretence to originality or learning, but which its compiler thinks supplies a decided need, is intended primarily for popular use. The student who wants to read the subject more fully is referred to Macalister's " Ireland in Pre-Celtic Times." Most of the matter herein embodied appeared originally in the pages of a re- 
vi PREFACE

ligious magazine, and it is from the suggestions of several readers, personally unknown to the writer, that the design of publication in the present form arose. If the little book be the means of making a few readers better, because more enlightened, lovers of their native land, it will have achieved its purpose.

For his kindness in reading the proofs and for some valued suggestions the Author begs to express his thanks to Mr. E. C. R. Armstrong, F.S.A. 


\section{ONTENTS}

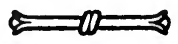

\section{CHAPTER I}

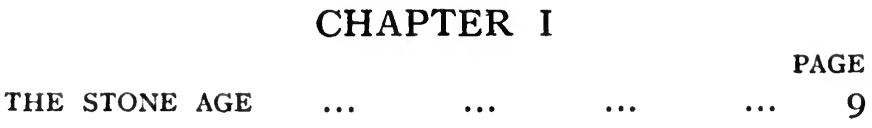

CHAPTER II

THE BRONZE AGE

$\ldots$
CHAPTER III

THE EARLY IRON AGE

$\begin{array}{llll}\ldots & \ldots & \ldots & 6 \text { I }\end{array}$

\section{CHAPTER IV}

ANCIENT IRISH RELIGION

... 85 
$=$ 


\title{
PREHISTORIC IRELAND.
}

\author{
CHAPTER I.
}

THE STONE AGE.

By prehistoric time we mean that remote period of human existence ere man had yet learned to write on stone or parchment the record of his deeds. Such 2 period there was-of immense and uncertain duration -and it did not end in this country before the $4^{\text {th }}$ or $5^{\text {th }}$ century of our era. It will readily be understood that prehistoric time is a relative, rather than an absolute entity: one race or people, like the Egyptian, may be well within the region of history at the same time that another, like the Roman, has not yet arisen, or a third, like the British, is still enshrouded in prehistoric gloom. Archæology is the science which enables us to reconstruct from the relics and implements the distant past has left us the story of this early time: it tells how the man of those days lived, how he housed and clothed himself, what food he ate and how he procured it, what weapons he fought with, the 
god that he believed in, and the art, if any, with which he beautified his life. The word archæology itself-from the Greek archaios, old, and logos, a discourse-suggests, and even fairly expresses, the scope and object of our science. Archæology is not, of course, concerned with all ancient things-only with ancient things of man's handiwork. Geological remains are therefore outside archæology's domainthough they are in fact immensely older than anything of human association.

Celtic archæology is the branch of antiquities which deals with ancient remains of the Celtic-speaking peoples; frequently, however, in our day and country, Celtic in this connection is incorrectly regarded as synonymous with Irish; it would prevent misunderstanding if we spoke of our national antiquities simply as Irish. Let the reader bear in mind that this island of ours was occupied by man very many hundred years before the first Celt appeared, and that, moreover, those pre-Celtic Irishmen have left relics innumerable in stone and bronze to tell us of their culture, as well as rude monuments of unhewn rock to testify to their hope of a life beyond the grave.

There was a time, thousands and thousands of years ago, when this fair land in which we live was covered by an ice-coat hundreds of feet thick and of generous fit. Not only, indeed, did the frozen garment cover the island from top to toe, but it extended into the Atlantic far beyond the western Irish sea- 
board; moreover, it joined Ireland to Great Britain, and the latter to the Continent. This period we call the Great Ice Age. The ice-sheet, it will be noted, was not permanent : there were various advances and recessions-each centuries long; there were also mild intervals between the advances, but these matters, as they rather pertain to geology, need not detain us. The enormous frozen mass is never quite at rest as it appears to be; after the manner of glaciers, it is ever in gentle motion towards the sea. $U p$ in the mountain ranges it wrenches rocks from their fastenings, and, gliding imperceptibly along, it carries them in its embrace, using them now as chisels to engrave the story, and again as ploughs to excavate, rollers to crush, and molars to grind. In its relentless course the mighty ice mass scoops out valleys, planes the mountain sides, and emits rivers from its melting centre. Pulverised rock, in billions of tons and liquid form, is carried down by the issuing streams, which deposit it near the edge of the frozen field or perhaps in the shallow sea-to become the smiling plain of future ages. Along with the pulverised rock come quantities of stone splinters, waterrolled pebbles, and even great boulders.

Of the great boulders thousands remain to the present day; examples may be found in every glenmute witnesses of the wonderful story I have outlined. To the glacial boulder class belong many of our dallans and some remarkable stone monuments, 
like Cloch Labhrais and St. Declan's Stone, County Waterford. Hundreds of the detached and rounded boulders primitive man found handy later on, when he desired to erect memorials of great events or to enshrine the ashes of his departed heroes. Time came at length when the scene of frigid desolation underwent a gladsome change. The ice cap slowly melted and the land gradually emerged, the temperature rose, and, with the genial climate, plants and animals of southern lands found their way into our islands, and northwards even to uttermost Scandinavia.

The first appearance of man in Ireland was, almost certainly, in Neolithic times. At any rate, we have no evidence of an Irish Palaeolithic man-a fact which does not preclude the possible existence of such a being. Here I must digress to explain that prehistoric time is commonly divided into three great periods-the Stone, Bronze, and Early Iron Ages, as they are called. In the Stone Age metal was unknown, and man's weapons and implements were of stone and such inferior materials as wood, bone and horn. The Bronze Age is the primitive period in which iron, the most useful and best of metals, was unknown, though copper, tin and gold were smelted and wrought. By the Early Iron Age we mean the time when iron first came into use. It must here be added that the Stone Age is again sub-divided into the Palaeolithic, or older, and the Neolithic, or newer, 
Stone periods. With the latter of these we shall have to deal more at length presently. The foregoing classic, and now universally accepted, division of prehistoric time we owe to some Danish antiquaries to whom it was first suggested by certain phenomena which they had observed in the peat bogs, or mosses of Denmark. Here, in these Danish turbaries, they noticed that the tree remains in the lowest strata were of Scotch fir-a tree which will not now flourish in Denmark and has not been native of that country within historic times. In the next ascending strata or layers the tree remains were of oak. The oak is now rather rare in Denmark and grows there but niggardly. In the uppermost layers the tree remains were of beech, which still grows freely in the country. This remarkable stratification of vegetable remains suggested to the investigators that great changes of temperature have taken place in Europe since the turf formation commenced.

This, however, was not the whole story which the turbaries had to tell-a story the full import and interest of which our archæologists did not at once appreciate. It was observed that, with the remains of fir in the lowest stratum, were associated stone objects and implements, that, in the middle strata, with the oak remains, were found objects of bronze, and, finally, with beech, in the uppermost strata, were found iron implements. The three classes of strata came gradually to be regarded as indicating 
three main and immensely separated stages of human progress, as well as great changes of climate.

The earliest traces of man so far found in Ireland have been furnished by the Larne gravels; the traces in question are roughly worked flints once used as cutting or scraping implements. Possibly of somewhat the same, or a not much later, age are the kitchen middens or prehistoric shell-mounds and other remains of a race of shore dwellers who lived largely on shell-fish. The camping places of this latter wretched race have been found in number on sand dunes and such places all around the Irish seaboard. Unfortunately, it must be confessed, the sites have not been scientifically and fully examined; the writer, indeed, ventures to suggest that the importance of our Irish shell-mounds and kitchen middens has not been yet realised; these refuse heaps have a wonderful story to tell, but it is only to the critical and trained observer that they will ever tell it. Somewhat similar remains in Denmark, which have been carefully examined, have shed quite a flood of light on the story of Stone Age Europe. One prehistoric shell-mound in Cork Harbour has been measured by the present writer and has been found to extend over a thousand feet long by eighty feet wide, and it must have stood originally ten or twenty feet high !

Preference of the earliest inhabitants for the sandy shores of the coast rather than for the richer interior 


\section{THE STONE AGE}

of the island is not hard to understand. With no weapons and implements other than pointed and sharpened stones these primitive people were ill-fitted to cope with woodland difficulties, including, as these latter did, great trees and tangled jungle, not to speak of wolves and wild boars. It was only when metal came in that man was able to make himself master of the forest-to clear it and to fight the wild beasts.

We have absolutely nothing to determine for us the exact period at which the first colonists arrived. The interval-for there was such-between Palaeolithic and Neolithic is known as the Messolithic, or more commonly now-Azilian, from the name of a French cave whence the remains of the intermediate period were first reported. For long it had been thought that, in the intermediate period referred to, man had entirely ceased to exist in Europe, so that, at beginning of the Neolithic, the Continent had to be repeopled. Evidence of an intermediate, or transition, culture had been sought in vain. To-day, however, in view of testimony from the cave of Mas d'Azil, the theory of complete disappearance is hardly tenable. Briefly, the Mas d'Azil cave-relics comprised in successive strata, remains of the Palaeolithic, Messolithic, and Neolithic cultures.

As, for reasons already given, it is practically certain the Palaeolithic had no place in Irish prehistory, we may dismiss it with a few observations. In Europe it was evidently of immense, but indefinite, 
duration, and many ancient types of men (Neanderthal, Cro-Magnon, etc.) belonged to it. Palaeolithic man was a savage; his home, when he had a home at all, was a pit in the earth or a rock shelter; his weapons were splintered stones and tree branches; he was mainly a hunter, and had neither an agriculture, domesticated animals, nor industrial art. Notwithstanding all this, however, we now know that this man of the dawn had a high artistic sense, and he actually painted and carved wonderfully realistic figures which are the puzzle and admiration of modern archæologists. From his remains, which modern research has brought to light, Palaeolithic man has been very fully studied, so that we can now reconstruct him to the life. We are able, for instance, to divide him into classes, cultures, races or well-defined types, and we know in what order these types succeeded one another.

Broadly speaking, the types derive their distinctiveness from character of the implements used, and they got their names from the places wherein the remains were first discovered or where they were found in peculiar abundance. First, there is the somewhat indefinite distinction into Drift men and Cave Men. The Drift man is so named because his rudely flaked implements are found in the glacial Drift, while the Cave man is so called from his habit of sleeping or sheltering in natural caves or beneath overhanging rocks. Secondly, from the 
varied character of his implements and other remains, Palaeolithic man of Europe has been subdivided into the Chellean, Acheulian, Mousterian, Aurignacian, Solutrean and Magdalenian culture, race or type.

The later of our two main sub-divisions of the Stone Age is the Neolithic, to which, provisionally, we assign the first Irish immigrants. Whence or how these people came we do not very definitely know. They can scarcely have come by land, for Ireland, even at beginning of the Neolithic, had already thrown off the gangway of land that had joined it to England, and England had become disjoined from the Continent. Be their manner of coming what it may, the aborigina! people of Ireland show affinity with the Southern European stock. Neolithic (from Greek, neos, new, and lithos, a stone) is the stage in which man polished his stone tools. Primitive man found that a hard stone, ground or polished to an edge, was a better cutting instrument than an unground stone. Every polished stone implement is as late, at least, as the Neolithic, but the converse of the proposition does not holdevery unpolished implement is not necessarily of the Palaeolithic. Indeed, a large proportion, and perhaps the majority, of Neolithic implements are unpolished, and it is from the stratum, or association, in which they are found, as much as from their character, that we determine their period. Generally 
speaking, Neolithic objects are found near or on the surface, while Palaeoliths are found beneath the surface. Data on which to calculate the beginning or duration of the Neolithic are vague and scanty; we know that the Neolithic was immensely shorter than the Palaeolithic, at least in Europe; we know, too, that the Neolithic ended in this country about 2,000 years B.C. Towards the close of the Neolithic we find, at any rate on the Continent, a crude knowledge of pottery and perhaps some primitive agriculture.

There arises out of our study of the Stone Age a problem upon which men have long and vainly speculated; it is the distribution of what are called cultural elements-the knowledge of fire, for instance, or metals or a particular implement like the stone axe or the boomerang. How has such knowledge come to be the common heritage of so many far-separated and non-related peoples? Is the diffusion due to former contact of the now sundered races or to independent invention, the result of uniform workings of the human mind confronted by the same difficulties? The former is called the convergence, and the latter the cultural cycle, theory.

Concerning the stages of cultural development, it is to be noted that the earlier are always the longer and the more difficult; this is why races remain such an immense length of time in the rude Stone Age; their sojourn in the age of polished stone is shorter, 
and their period in the age of Bronze still more brief. Soon as primitive man begins to make better, because more effective, weapons-polishing his axes, etc., his progress becomes faster, and when, at.last, he discovers metals, his advance becomes really rapid. It is invariably the first step in the ladder of progress which is the most painful to negotiate; succeeding eps grow less and less difficult.

From present-day primitive peoples we may learn much about our ancestors of the Stone Age. It is generally recognised that-as neither advance nor retrogression, but comparative permanence, is the law of the uncivilised-the savage and barbarian races of to-day are closely allied in their material condition, methods of life and thought, etc., to primitive man as his remains make him known to us.

Discovery of fire was one of the first forward steps of early man. There can be little doubt the discovery was always accidental. How important early men :egarded it we may gauge from the fact that they always attributed the invention to the gods. The accidental striking together of two pieces of stone, or friction causing wood to smoulder, may have first suggested the idea of fire-production. Primitive men produce fire in two ways : by flint and tinder and by friction. Pieces of iron-stone, which were evidently used as strike-a-lights, have been found in French Palaeolithic caves. Some of us are old enough to remember the time when countrymen commonly 
lighted their pipes by means of flint and steel. Possibly, however, the friction methods were the older and more popular : they were mainly three :-(a) the rigid saw, (b) the drill, and (c) the flexible saw, methods. The rigid saw method required a piece of wood in which a shallow groove had been cut and filled with fine dry wood parings. Across the groove and the first piece a second piece of wood was made to run backward or forward with a rapid saw-like or file-like motion, till, in less than five minutes, sufficient heat was generated to ignite the wood parings. The drill was a small pointed piece of wood made to revolve rapidly between the palms while its pointed end was held in a scooped-out hollow into which tinder had been put. In the flexible saw method a section of rope, or withe, or bamboo was substituted for the second (sawing) piece of wood while the first (grooved) stick was held steady by the feet. To produce fire by any one of the primitive methods enumerated is not very difficult, as the reader with a taste for experiment may prove for himself.

Man of the Stone Age, we may take it, was not over particular about his cooking. Possibly, during the Palaeolithic, he mostly preferred to eat meat raw; probably most of the time he had no choice. Among the aboriginals of Australia to-day, as the writer can testify from observation, only the most elementary cooking is done, although the Australians are really in the Neolithic stage. The carcase-skin, hair (or 
feathers) and all-is cast into the embers and hauled out again to be eaten before skin or feathers are much more than singed. Nay, the writer is bound to confess, sometimes the game is not laid on the fire at all, but eaten entirely uncooked. Gradually, we may suppose, men learned that meat became more palatable for being boiled or roasted. Roasting naturally preceded boiling, a tree branch or twig serving as a spit. Very likely man had advanced to the Neolithic stage before he commenced to boil his meat. 'At any rate, it is only in his Neolithic age that he began to make pottery, but of course it is possible to boil water without vessels of clay or metal, and Neolithic man, although he had earthenware vessels, often preferred to do his boiling without them. He filled a hollowed-out tree trunk with water which he brought to boiling point by dropping into it red-hot pebbles or small flagstones. Another method of primitive cookery was to lay meat on a heated flagstone or in a pit floored with flagstones upon which fire had been piled.

Discussion of primitive cooking suggests reference to a very common Irish prehistoric monument-the Fulacht Fiadhaigh (cooking place of the venison). This, which is generally found beside a stream or well, consists of a mound of small burned stones and ashes from a couple of yards to thirty or forty feet in diameter. Within the mound is generally found a wooden trough. Though probably the most com- 
mon of all our ancient monumenẗs, the fulacht has been very little investigated. The popular view is probably quite correct which assigns this class of monument to an exceedingly remote period when cooking pots were unknown or very rare and boiling was effected by the expedient of dropping heated stones into the water. The wooden vessel is the cooking vat and the blackened stones are the pieces used to bring the water to the boil.

Cookery, again, suggests pottery. It is probable that our Stone Age Irishman, like men in a similar stage of culture on the Continent, had-at least, towards the close of the Age-some knowledge of the potter's craft. The potter's is almost the first art which primitive man learns. Its discovery, like the earlier discovery of fire, is jy accident. Somebody, perhaps, overlays his wicker-basket with clay to make it water-tight, and as the basket stands near the fire the clay dries and hardens, retaining the shape given to it. Or, it may be, it is a woman idly sitting by the fire who notices how the print of her foot in what had been soft earth has become solid by heat action. Finally, probably it is a child-aimlessly scratching the drying vessel with a piece of wood or bone-who first reveals the clay's capability of receiving and retaining decoration. The earliest ornament was simple line pattern, with perhaps some nail marks, or a string was passed round the vessel and tightened till it sank somewhat into the soft material. 
The characteristic implement of the Later Stone Period is the polished stone axe-head or celt. That name, celt, by the way, has a curious origin; it is derived from what is called a nonce word, that is, a word which appears only once in literature. The original word is celte, which occurs in the Latin Vulgate version of the Book of Job, where it is used to signify a chisel. Stone axe-heads have been found in almost all parts of the globe-evidence that men in a similar state of culture adopt the same means in like circumstances the whole world over. Its synonym, "stone axe," implies that our celt somewhat resembles a small axe in shape. The stone axe, or celt, has no socket hole for a handle; the t:andle was not inserted in the celt, but the celt was inserted in the handle. "Hafting" is the term applied to the operation of furnishing the stone axe with its handle. Often, of course, the celt was intended to be held in the hand without a handle, and when this was the case the upper end was sometimes embedded in gum which was then covered with skin. Let us, however, suppose the implement is to have a handle; the hafting is simplicity itself; a piece of wood is cleft or split for two or three inches at one end and into the opening the stone head is inserted, the two sundered parts are tightly bound with withe or tendon or raw hide above and below the axe-head, and the whole is further secured by gum, resin, or cement. In a few cases stone axes 
have been found in bogs, still clasped in the original handle. Occasionally the handle was merely a flexible branch twisted tightly round the axe-head, and sometimes the head was cleverly wedged into a handle of antler. The writer has met one case in which the implement was hafted by nature: the axe-head was placed in the fork of a young growing tree and left there till the tree had grown quite around, hafting it automatically. Unless special care is used in drying the axe-handle, or any ancient wooden object found embedded in a turf bog, it twists out of shape and flakes away in splinters. Such wooden antiquities should be kept moist till handed to an expert for drying. The objects are first steeped, or even boiled, in a strong solution of alum, and afterwards slowly dried. The axe-head tapers, as a rule, from cutting edge to back-that is, it is wider at the edge than at the non-cutting end; also the edge is usually crescent-shaped, at least in Irish examples. Sometimes only the edge and its immediate vicinity are polished, at other times the grinding extends to the whole surface of the implement. Probably the complete polishing of the axe was æsthetic rather than utilitarian in purpose. As in finish, so in material and size-stone celts vary widely. A hard-grained stone-the hardest available-furnished the material. In Ireland, flint, notwithstanding its extreme hardness and probably because of its scarcity and its narrow area of distribution, is a rather 


\section{THE STONE AGE}

rare material for celts; in Scandinavia it is otherwise. Chert, greenstone, basalt, slate, and even granite, limestone and hard-grained sandstone were the raw material used by the Irish celt-maker.

When the primitive Irish hunter wished to make himself an axe he first sought a piece of stone-preferably a water-rolled pebble-of the requisite hardness and of suitable size. When stone of the desired quality was not available on the surface his English contemporary did not hesitate to bore for it till he met in the quarry a vein of the kind wanted. By means of a hammer-stone or a pick of deer horn the pebble, or quarried piece, was reduced, through flaking and hacking, to somewhat like the size required, and then, by a few additional light touches, it received its shape. Lastly, protuberances, etc., were removed by hammering, one end was ground to an edge, and the whole surface (or portion of it) was polished by rubbing and by use of sand and water.

I have already stated that neoliths are found at or near the surface. Stone celts are turned up occasionally by the plough or spade. They are found in crannogs or ancient artificial islands, in turf bogs, on old inhabited sites, and, most of all, perhaps, in fords or crossing places of rivers. There is no more unlikely place for discovery of a stone axe than the middle of a main public road-yet in such a situation the writer once found a nice specimen. 
The axe was coated with clay, and, presumably, it had been flung, perhaps at a bird, dog, or trespassing fowl, from a labourer's tillage plot by side of the road.

In Ireland the stone arrow head-generally of chert, flint, or quartz-is found more commonly than the celt. The arrow itself, of which our wrought stone formed the tip, has never been found, and we need never expect to find a specimen. The reason is obvious; with the bow which propelled it, the arrow shaft has decayed long ages ago. We are dependent, in fact, upon the discovery of arrow heads for our knowledge that the Stone Age folk of Ireland ever used the bow. Arrow heads vary in length from half an inch to two inches, and they are of diverse patterns-triangular, leaf-shaped, lozenge-shaped, tanged, stemmed, and barbed. Some of my readers do not require to be told that in parts of Ireland ancient arrow heads are regarded with superstitious reverence. Indeed, the superstition is not confined to Ireland-or perhaps to Europe. A few years since the writer saw some beautiful arrow heads in the hands of quack cattle doctors in a certain western county. Money could not purchase those objects, nor eloquence extort them; they are regarded as infallible remedies in cases of cattle disease; the fairy stone, or dart, as the arrow head is called, is put into water or other liquid which the cattle are made to drink. Origin of the "fairy dart" is be- 


\section{THE STONE AGE}

lieved to be supernatural; the diminutive weapons were shot by "the good people" at the cattle. In their turn the wound producers act as antidotes.

Somewhat similar in shape and character to the arrow-head, but larger and heavier than the latter, is the javelin-head and the spear-head. A spear differs from a javelin in being stouter and of greater length. The javelin was flung or cast, while the spear was used for thrusting.

Other stone implements of fairly common occurrence are the stone-hammer, the hammer-stone and the axe-hammer-objects the names of which sufficiently indicate their character-the rubber, the scraper, and the spindle-whorl. The spindle-whorl was used with the distaff in primitive spinning. It is a small flat ring of stone or of baked earth, two inches or so in diameter. Spindle-whorls are frequently turned up by the plough, and their finders call them "stone washers." They were, and sometimes still are, believed to have been the wheels of fairy chariots. The scraper is one of the simplest forms into which stone flakes are capable of being easily worked. The implement is really a flake, more or less circular, the outer rim of which has been chipped into a bevelled edge. A very common type of scraper is shaped like an oyster shell. Such an implement might be useful in planing wood or dressing skins. Scrapers are found of very diverse patterns-circular, semicircular, oval, horseshoe-shaped, toothed, gapped, 
convex, concave, etc. The rubber is a rudimentary mill-stone. It takes, like the scraper, a multitude of forms. Ordinarily the rubber is a small piece of flagstone used for titurating grain, edible roots, or pigments. Rubbers go, like mill-stones, in pairs-an upper and a lower; the former, generally circular or oval, with a flat or ovoid undersurface, is held in the hand while it is made to crush-by rubbing rather than by pounding - the material placed in the shallow basin of the under rubber. The rubber is really the prototype of the quern $:$ in its development it becomes (a) the "saddle quern," a shallow stone dish with a kind of rolling-pin crusher, and (b) the true quern or stone mill of a later period. The true quern or hand mill, which continued in use till within the memory of people still living, consists of two parts-the bró uachtarach, or upper portion, and the bro iochtarach, or lower half. The spindle, upon which the upper part revolved, was of hard wood and was set in the lower stone; it was named the boircín, while the little block set in the upper stone into which it fitted was called the cuib.

The most important, if not the greatest number, of our rude stone monuments belong to the Neolithic and to the later portion of this period. It will be appropriate, therefore, that we discuss the megaliths, as the monuments in question are called, before proceeding further. Of Irish megaliths the dolmen is the most interesting, as the standing stone is the 


\section{THE STONE AGE}

most common. Other classes are the cistvaen, the bullán, or stone basin, the stone circle and the hill-top cairn.

The Dolmen, because of its structural importance, its very distinctive character, its wide distribution and ethnic significance, will require a somewhat extended notice. In Ireland it is vulgarly called cromlech. This name is, however, so very incorrect that no apology is needed for refusal to recognise it even as a synonym. As the reader may surmise, the true name, Dolmen, is not Irish; it is nevertheless Celtic and it comes to us from the Breton, in which it signifies-stone table (dael maen), a really appropriate name. The name, cromlech, is proper to another, and very different, class of monument about which we shall have a little to say later.

A Dolmen is a rude stone structure of tomb type, composed of a certain number of great stone uprights which support a capstone, or capstones, as a roof. In a general way, the monument suggests a house; it also suggests a tomb; indeed it was both-the tomb of the deceased and the house in which dwelt his ghost. As a rule the covering slab inclines at an angle, but the dip, or inclination, seems to be without significance-usually the result of some settlement, or displacement, of an upright. Again, the east-and-west alignment of the monument has, under the name of Orientation of the Dolmen been the subject of much argument and speculation which the 
writer cannot help thinking extremely futileSir Norman Lockyer, Stonehenge and the Pyramids notwithstanding.

As a natural consequence of their enormous age and their exposure for untold centuries to all sorts of denuding and destructive agencies, also because of the immense weight of the covering stones, many of the dolmens-perhaps the majority of them-are now in a ruinous condition. Water, softening the ground around, has caused uprights to slip or sag or sink. Cattle sheltering beneath the capstone have helped to bring down the latter or, perhaps, one of its supports. Idle youths have wrought their mischievous will on the hoary megalith, and the covetous farmer, the vandal road contractor, and the builder of mansions and labourers' cottages, have used the monuments as quarries. The wonder indeed is that, with so many enemies, natural and human, the dolmens have survived in such numbers.

Here, arising out of what has been just said, the theory of Messrs. Worsae and Lukis claims notice. Worsae, a distinguished Danish archæologist, held -and he is supported in the matter by Lukis, an eminent English investigator-that all dolmens were originally encased in, or covered by, mounds of earth or cairns of stone. If the mounds or cairns, they say, no longer remain, it is only because they have been removed, the one perhaps by nature, the other by man. One may argue $e$ contra that after the prodigious 
labour expended on the erection of such a stone chamber, surely no one would be mad enough to bury the whole beneath a mass of earth and stone, clean out of human sight. To argue thus, however, is to beg the question and imply that we fully understand the builders' motives and the religious notions which animated them in their work. It must be admitted the dolmens, as we know them, show no trace, or hardly any, of mound or cairn. We must, however, on the other hand, remember that cattle and sheep have grazed over the structures for untold ages, that foxes and rabbits and dogs and treasure seekers have burrowed and dug into them, that the rains and storms, the summers and winters of forty centuries have beaten upon them, and finally that man has coveted their poor materials and grudged them the few feet of earth they occupied. Borlase, whose great work, "The Dolmens of Ireland" (3 vols.), though none too accurate, is the standard work on the subject, adopts Worsae's theory at least generally. He does not, however, claim, as Worsae seems to have claimed, a mound of earth in every case. In many cases he would admit there was only a pile of small stones carried around the uprights up to, or about, the height of the capstone. It is very easy to understand how, in the course of a few hundred years, mould would accumulate upon the stones and give them the appearance of an earthen mound. The uprights, forming supports of the capstone, are 
so placed in the dolmen as to enclose a kind of rude, more or less oblong, chamber, closed at both ends by broader boulders or flag stones, which we may regard as rudimentary gables. The chambers may be six or eight feet long by four feet wide and from five to eight feet high. People sometimes wonder how men, without machinery or knowledge of the pulley, were able to lift the heavy capstones into position. We do not know for certain how exactly the feat was accomplished, but it was surely by some combination of rollers and the inclined plane.

Dolmens we may divide into types or classes. There are dolmens the capstones of which are entirely supported on the uprights, while in others one end of the great capstone rests on the ground or upon a very low stone. We call the first a secondary and the second a primary, or earth-fast, dolmen. Earthfast specimens are generally of great size. Browne's Hill Dolmen, near Carlow, is of this type and its capstone is estimated to weigh one hundred tons. The beautiful dolmen in the Giant's Ring, near Belfast, is an example of the secondary type. A second division of dolmens is suggested by the way in which the capstone rests on the uprights. Sometimes the single capstone rests directly upon the uprights as in the Knockeen Dolmen, near Waterford; at other times, as in the well-known Leac-an-Scail monument, near Mullinavat, Co. Kilkenny, the capstone rests, not immediately upon the uprights, but upon an 
intermediate or secondary block introduced between it and the uprights. A dolmen with a number of secondary blocks introduced between capstone and supports is somewhat suggestive of the Bronze Age chamber within Newgrange tumulus. Finally, I think, we may divide dolmens into one and twochambered varieties. In the one-chambered type there is a simple oblong apartment only; the doublechambered has, in addition to the principal, a second, or smaller and imperfect, compartment, resembling a porch or ante-chamber. The Knockeen dolmen, already alluded to, is an example of what I have called the double-chambered variety; our singlechambered type is represented by the Shanganagh and Druid's Glen dolmens, Co. Dublin.

The geographical distribution of the dolmen is a matter which has been attracting a good deal of attention of late years. More than one learned brochure recently issued from the University of Manchester is concerned with the problems involved. Suffice it for our present purpose to know that Ireland is but a little link in the chain of dolmen-yielding lands, which extends from Scandinavia in the north to distant India and beyond. There are a few dolmens each in Sweden, Denmark, Germany and Holland. A few have likewise been recorded from England and they are quite numerous in Wales and Cornwall. In France they occur in enormous numbers-chiefly in Brittany and along the Atlantic seaboard. The 
total number of dolmens in France is set down as 3,410 . In decreasing numbers they occur in the Iberian peninsula, mostly along the western coast. Across the Mediterranean, and along the north African coast, we pick up and follow the far-flung line. Here, however, it is not by any means an unbroken chain. We find quite a gap at Egypt, in which country no dolmens are found. Beyond the Jordan the line is picked up again, and it is traceable the whole way into Central India, and even, it is claimed, to distant Japan. The total number of Irish dolmens recorded by Borlase is seven hundred and eighty-six. Although Borlase enumerates as dolmens some monuments which are, almost certainly, not what he makes them out, it is extremely probable-to the present writer, indeed, quite certain-that Borlase's estimate errs by defect. Many existing monuments have not been recorded; for instance, the writer has found, in one county (Waterford) alone, five dolmens not hitherto noted, and unknown to Borlase. Generally speaking, dolmens abound most in the maritime countries; some of the inland counties, v.g., Kildare, King's County and Westmeath, do not possess a single specimen. Sligo has the largest number-one hundred and sixty-three. Donegal has eighty-two, Derry twenty-two, and Antrim twenty-nine. Along the east coast Down has nineteen, Louth four, Dublin fourteen, Wicklow nine and Wexford two. Kilkenny, though it does not 


\section{THE STONE AGE}

touch the sea, has the comparatively high total of twenty-eight, which is eight more than Waterford; Cork has seventy-two and Kerry twenty-two. On the western coast Limerick is credited with nineteen dolmens, Clare with ninety-four, Galway with thirty, and Mayo with forty-five. It is quite certain that scores, if not hundreds, of monuments additional have been destroyed, leaving neither remains nor memory behind.

Along with the other fantastic notions of the wild Vallancey school the theory that the dolmens were druid altars is now quite discredited. In their perfervid imagination some of the pagan-altar theorists saw, I believe, in the covering-stone the channels cut to carry off the victims' blood, and even, in a few cases, traces of the actual blood itself! The theory was romantic, and that was enough to commend it to the unscientific archæologists and historians of the eighteenth century. Dolmens were not, of course, altars at all, but tombs or cenotaphs, as remains of burials found in them sufficiently indicate. In many monuments examined in recent times no burial remains have been found; in explanation it is only necessary to remind the reader of the enormous antiquity of the burials, and also that the majority of the monuments were rifled long ages ago.

It is doubtless to their sepulchral character that dolmens owe their popular designation of Leaba, a bed. The Irish leaba is a bed indeed, but a bed in 
the sense of a grave; thus the saint's grave is styled his leaba. Dolmens are popularly and variously known as-"Leaba Diarmuda agus Grainne," "Leaba na bhFiann," "the Giant's Grave," etc. A small dolmen in County Waterford is known as "Leaba Thomais Mhic Chába." One might conclude that MacCabe was some poor wanderer who, perhaps, used the monument as his sleeping place or who was found dead therein; but when he finds the same name applied to an oblong depression in the limestone rock of the middle island of Arran, he recognises in it an echo of a once widely diffused legend or piece of folklore. Similarly another small dolmen, on the edge of a cliff near Mine Head, on the southern Irish coast, is called "Tigh Caillighe Bheara.' Caille Bheara is a legendary female personage whose name is found attached to ratural and artificial objects all over Ireland.

A near relative of the dolmen is the Cistvaen, or Giant's Grave, if indeed we do not regard it as really rather a variety of the dolmen than a monument of distinct type. The cistvaen consists when perfect-which, by the way, it seldom is-of an oblong, slightly sunken, and flag-roofed chamber or cist, the sides and ends of which are formed of large boulders. Our monument's most characteristic feature is, however, a circle of standing stones which surrounds the cist; the circle, by the way, we may look upon as the kerb or retaining wall of the mound 


\section{THE STONE AGE}

or cairn which formerly covered the chamber. A cistvaen, then, differs from a dolmen in (a) greater length of chamber, (b) substitution of a series of large flag-stones for the great capstone of the dolmen, and $(c)$ presence of a surrounding stone circle or kerb. Again, the cistvaen differs from the simple cist in the greater length of the former and its possession of a stone kerb; the simple cist has no such kerb, and it is of small size-only about three feet square. It is safer, in fact, to regard the cist as a Bronze Age monument. Like dolmen, the word cistvaen comes from the Breton, in which it signifies-stone chest. The cistvaen, rather than the dolmen, is the Giant's Grave of popular belief. Even as long ago as the distant days of St. Patrick, the Giant's grave was looked upon with awe as the last resting place of gigantic men. In one of the ancient Lives of the National Apostle, edited by Colgan, the statement is made that, as Patrick was once travelling in Connacht, he passed, by the wayside, a prehistoric tomb of this type. His companions expressed their belief that no human being could possibly require so long a grave, whereupon the Saint-to prove to his halfdoubting disciples the Life to come-called back from the dead the gigantic tenant of the tomb. Incidentally the legend shows that, in the early Christian period, the cistvaen was regarded as a tomb, and that ten or fifteen hundred years ago its origin 
was as much a mystery as it is to-day. On the whole, probably the cistvaen is of more frequent occurrence than the dolmen; it is, however, because of its insignificant height, less likely to attract notice. Often, indeed, the cistvaen has almost disappeared beneath the accumulating earth and vegetation. It may be looked for in wild and uncultivated places and even on hill-tops where the true dolmen is seldom found. One of the most perfect cistvaens known to the writer crowns the high, furze-clad summit of Knockadirra (Kilmacomb) Hill, near Dunmore East, County Waterford.

Not unrelated to the dolmen and cistvaen is the Carn or stone pile, found usually in rocky and hilly country, very often on peaks of mountains. On peaks of the Dublin mountains, for instance, overlooking the Capital and plain of the Liffey are several very familiar carns, some of which have been opened and explored. Another well-known example is Mioscan Maeve, an enormous pile crowning a remarkable mountain peak to west of the town of Sligo. Carn Tighearna, near Fermoy, Co. Cork, is almost as well known as the last, but, unfortunately, it is not as well preserved. As, however, the carn is really more a Bronze, than a Stone, Age monument, we may postpone further notice of it. Suffice it for the present to say that the monument is generally furnished with an internal chamber (or chambers).

The Leacht somewhat resembles the Carn, with 
which in the beginning it was probably identical. It is an unchambered pile of comparatively small stones, and its name signifies "grave monument." In more modern times the leacht seems to have become merely a cenotaph or memorial, to mark, for instan 'e, the scene of a murder or other such tragedy. In their capacity of simple memorials leachts have been erected in quite recent times. When the word leacht occurs in a place-name-as it often does-it is, as a rule, to be taken in its earlier (or "grave monument") sense.

Among Irish rude stone monuments the Dallan, or pillar-stone, holds a very important place; for one thing, it is the most frequently seen of them all. There is hardly a parish in Ireland-at any rate outside the Pale and urban areas-in which a pillar-stone is not to be found. The pillar-stone is not necessarily Neolithic. A large percentage of the existing specimens are, no doubt, of the Bronze Age, and many are of later date. There are cow-stones, etc., set up in our own day-hardly to be distinguished from the venerable megalith which has stood since the prehistoric dawn. Generally the true pillarstone may be distinguished from its modern simulator by its greater size, and by the popular veneration-not unmixed, perhaps, with dread-which hallows it. Other names for the dallan are :-Gallán, Liagán and Cloch Fhada (Long Stone), and each of these words enters into the composition of quite a 
large number of Irish place-names. The scientific name, by which the object is known to Continental scholars, is menhir, from the Brythonic maen, a stone, and hir, high. In Irish-speaking parts of Ireland-v.g., the Munster Decies-the name, Fear Bréige is sometimes applied to a pillar-stone standing on a mountain ridge and-seen silhouetted against the sky-line, from the plain below-simulating the outline of a man. In Scotland pillar-stones are called cut-stones-not, presumably, from any association with poor tabby, but from cath, a battle. Pillar-stones are, of course, always undressed by hammer or chisel, and they vary in height from three or four to eighteen or twenty feet. A Breton dallán, shattered some time since by lightning, stood sixtyfour feet high! The menhir we may regard as the expression of an instinct as old as humanity, to commemorate in a rough but effective way some notable event-a battle, a treaty, the death of a warrior-or to mark the tribal boundary or the last resting place of the mighty dead. There is good reason to believe, too, that many pillar-stones, like the pillar-stone on Tara Hill and the fine specimen at Giant's Grave, near Clonmel, were once worshipped as idols. In connection with the pillar-stone's memorial character, we may . call the pillar raised by Jacob on the spot where a vision of glory had been vouchsafed him; perhaps, too, we may remember a stone set up in a certain Irish city to commemorate a treaty broken 
"ere the ink wherewith 'twas writ could dry." Memorials of Christian missionary or early anchorite, of Niall's conquests or Tara's glory, have disappeared, but the unhewn pillar-stone which has stood from the youth of time, which was hoary with age before Niall rose or Tara got its name, stands defiant as of yore. It saw the beginnings of history; it may be that it is destined to see its end.

The Stone Alignment is a row, or avenue, of pillarstones apparently allied to, and often associated with, the Stone Circle. The alignment seems rather rare in Ireland, at any rate it has not been much reported on and described; perhaps it has not been regarded as a distinct class of monument. The alignment is better known in England (Dartmoor, Kenidzhek and St. Breock Downs in Cornwall, etc.) and Brittany. Several stone alignments in Co. Cork, v.g., Castleleacht, Ballindeenisk, Barrachaurin, etc., have recently been examined by the present writer, and in all the instances the monument was found very imperfect. What was the purpose of the alignment? Is the monument sepulchral, memorial, religious or astronomical? It must be confessed that, so far, archæology is unable definitely to answer; it is extremely probable that the primary purpose was sepulchral.

The Stone Circle sets, as Sir Bertram Windle ("Remains of the Prehistoric Age in England") well observes, a more difficult problem than any of 
our other rude stone monuments, except, perhaps, the alignment. First, let us surmise that there are various kinds of stone circles, and that the stone circle of which we speak here is not the ring kerb of a mound but a circle of naked standing stones (from two to eleven feet high), surrounding a space from fifteen to forty yards in diameter. At Wattle Bridge, Co. Fermanagh, there is a well-known example of such a circle. There is also a fine specimen at Castletown Bere, Co. Cork, and lesser monuments at Lough Gur and elsewhere. Stonehenge and Avebury, in England, which, for adequate description, would each require, not merely a page, but a chapter to itself, are stone circles on a gigantic scale. There is a strong tendency to-day to regard the stone circle as astronomical in its purpose, but it is difficult, in face of the evidence of associated burial mounds and cists, to accept the idea that their purpose was not primarily, or in part, sepulchral, like the dolmen's. 


\section{CHAPTER II.}

THE BRONZE AGE.

THE most important forward and upward step which man, in his cultural evolution, ever took was, most probably, the step which raised him from his childhood of stone to his youth of bronze. Indeed the step from stone to metal is, for all practical purposes, the advance from savagery to approximate civilisation. One of the most apparent and intimate points of relationship between metals and civilisation is this : it was metal which first enabled man to attack the primæval forest and to till the earth.

We can conjecture, with plausibility if not probability, the manner of metal's first discovery. The first metal found must have been either copper or gold; the glistening colour of the gold nugget or the glossy sheen of the native copper would be sure to attract attention; examination and experiment would show that, unlike all previously known stones, the new and wonderfully coloured stone is malleable and fusible. Without prejudice to the question of prior discovery we call the earliest metal period the "Age of Bronze," 
rather than the "Age of Gold," because copper, the chief constituent of bronze, was the more useful, plentiful and prominent of the two metals.

Bronze is a mixture, or alloy, of copper and tin in various proportions according to the purpose for which the bronze is required. For strength-and hence for tools and weapons-the proportion is about ten parts of copper to one part of tin. The proper proportions would be learned from experience, but how man got his first knowledge of alloying is a problem that can never be solved. In some way or another -almost certainly by accident-it was discovered that bronze made better cutting implements than pure copper, and henceforth the alloy-to total exclusion of the pure metal-is used for industrial purposes. The word " copper" (Latin, cuprum and aes Cyprium) is derived from the metal's ancient association with Cyprus, from which island Europe's earliest supply was procured. 'Though Cyprus did undoubtedly have a good deal to do with the early supply of copper, native copper was worked independently from very early times in most countries. Thus, there is abundant evidence that in Ireland, from close of the Stone Age, various localities were worked for copper. The main supply would appear to have been derived from the counties of Waterford, Wicklow, Cork, Kerry and Tipperary. Traces of prehistoric workings have been found in the copper-yielding districts of Waterford and Kerry. In the writer's possession is a 
prehistoric copper ingot from Bonmahon, and our museums possess stone hammers, etc., from the Kerry mines. Tin, the minor constituent element of bronze, probably attracted attention by its weight, and it is not unlikely that its use as an ingredient of bronze resulted, on the first occasion, from the addition of a small quantity of tin to the copper to eke out the mass of the latter which had run short. The resultant mixture was found to be superior to either of its constituents, and it required only a little experiment to determine the exact proportion of the two metals to produce the best results. No ancient implements of tin have ever been found, and the finds of pure-copper objects are so few that some have gone so far as to deny the existence of a Copper period proper. These authorities explain the occasional manufacture of pure copper objects on the ground that the latter was rare and took place only when the store of tin was exhausted. Rarity of copper objects is, however, otherwise explicable, namely, on the ground that of the copper articles originally made the vast majority would, at a later date, be resmelted to be mixed with tin and recast as bronze.

Both copper and tin are supposed to have been originally discovered somewhere in the mysterious heart of Asia. Our earliest evidence of their use is furnished, as usual, by Egypt; the copper mines of Sinai were worked by a king of the 3 rd Dynasty 
about the beginning of the fourth millennium, B.C., and the earliest piece of bronze known is a rod found at Medum, and dated from about 3700 B.C. Indeed there is a probability that copper was known both in Egypt and Chaldæa as early as 5000 B.C. ${ }^{1}$

The copper-mining methods of early men were the simplest. Mostly, as has been said, the primitive workers used native metal or alluvial nodules. When they came to work ores, great fires were lighted against the rock face, upon which, when it had become quite hot, cold water was poured, and the detached mass was broken to fine pieces by stone mauls. Smelting was done in pits or kilns of burning charcoal.

At the outset of our study in bronze it is important that the chronology of the Age should be fixed-at least approximately and as far as such determination is possible. Fortunately for our purpose much light has of late years been shed on this phase of the subject. Archæologists are now agreed in assigning to metal-working in Western Europe a much greater antiquity than was formerly allowed. In such matters as the present it will be remembered that dates are only approximate, and that it is rather a succession of types that the archæologist regards. Hitherto, or till quite recently, an unduly long period -two or three thousand years-was allowed for spread of the metallurgic art from Egypt, or the near

1 "Prehistoric Man," Scott Elliot. 
East, to our remote Irish shores. The period postulated is unnecessarily long, for other, and less important, arts found their way across the continent in an immensely shorter time. The older authorities set down about 1000 B.C. for the beginnings of metal in these islands. Dr. Oscar Montelius, of Stockholm,-the foremost modern authority on the Age of Bronze-in his Memoir published in 1908, places the commencement of Britain's Bronze Age at from 2500 to 2000 B.C. In this general estimate he is followed by the best moderns, including $\mathrm{Mr}$. George Coffey, of our National Museum, who, however, modifies somewhat the dates of the Swedish scholar. Montelius distinguishes the Bronze Age into five periods, or epochs, somewhat as follows :I.-The Copper Period (2500 or 2000-I800 B.C.). This is the interval between the first knowledge of metal and the invention of bronze. During this period stone axes, etc., continued to be used side by side with the more serviceable implements of metal. The copper axe is extremely simple in form-a mere flat, ridgeless reproduction in metal of the stone celt. Primitive daggers, with a broad, flat, and generally rivetless tang, belong also to this period, as well as a number of objects in jet, amber and gold.

2.- The First True Bronze Period (1800-1500 B.C.). Stone implements have been almost entirely superseded, and, though the axes are still flat after 
the model of their stone prototype, they have grown broader and somewhat crescent-shaped at the cutting edge; moreover, they are occasionally flanged-that is, furnished with slight ridges at the hafting end to hold the handle rigid. This flange is a feature of some interest, as its development later resulted in the socket. In this period the dagger has grown somewhat larger and longer, and sometimes it is fastened to its handle by metal rivets. The halbert, a short pick-like implement not unlike an abbreviated scythe, makes its appearance; it is probably an evolution from the more primitive pick of tree branch or antler.

\section{3.-The Stop-Ridge Period (1500-1250 B.C.).} The "stop-ridge" is a slightly raised band on sides of the axe and roughly parallel with its cutting edge, designed to prevent the slipping down of the handle. Bronze sickles belong to this period as well as bracelets and torques of gold.

4.-The Socketed-Axe Period (1250-900 B.C.). Growth and increased prominence of the flanges and stop-ridge have produced the socket. Leaf-shaped swords, socketed spear-heads, gold torques and disc-headed pins belong to this period, to which also may be ascribed, at least approximately, the great tumuli of Newgrange and Loughcrew. This fourth Bronze Period corresponds, by the way, with the beginnings of iron in the $Æ$ gean; it was roughly the period of the Trojan War and the Homeric 
poems, of Egyptian and Cretan decline, of the Israelite settlement in the Promised Land, and of Etruria's rise to artistic and cultural eminence.

5.-The Last Bronze Period (900-350). This period was of great duration. To it belong our looped and socketed celts, our winged palstaves, our trumpets, and wonderful fibulæ and gorgets, which have long been the envy and the admiration of foreign antiquaries.

It may be useful here to outline the arguments of the moderns-Montelius, Sir John Evans, Lord Avebury, and Coffey-in favour of setting back the beginnings of bronze to the commencement of the second millennium B.C. First, the development of so many new and varied forms requires an immense period of time. Avebury would require five hundred years, at least, for each of the five periods of Montelius. Secondly, if metal was known in Egypt four thousand years B.C., knowledge of it could not (judging by analogy) have taken more than a couple of thousand years, at most, to reach Western Europe. Thirdly, many of the copper and early bronze objects found in these western islands are of the simplest and earliest types, a fact which indicates that the art of metal-working, or, at any rate, the knowledge of metal, travelled rapidly. Had it not done so, the carliest metal objects to be found in these countries would be not the flat and simple, but the more developed and perfected, types. The 
earliest wave of culture always travels more slowly than subsequent waves; in the case under consideration, unless the initial wave had advanced with the rapidity implied in the theory of Montelius, it would have been overtaken on the way and left behind by waves of later origin, and the simplest form of bronze implements would never have survived to reach Western Europe.

"Finds" of Bronze Age objects are of three classes: (I) objects lost, (2) objects buried with the dead, and (3) hoards. Finds of the first class are the most frequent; they occur especially at ancient places of assembly, at fords or river crossings, on battle sites, and in the neighbourhood of great forts and high roads. Objects of the second class owe their inclusion in ancient burials to the idea that the life beyond the grave was a glorified continuation of the earthly life, and that the dead man would require, in the region beyond, food, weapons and tools such as he required on earth. The third class of finds is far the most important, inasmuch as the articles in a hoard would be more or less contemporaneous-a fact which oftentimes enables the archæologist to fix the age of an object. Hoards, again, are of two kinds-treasure-hoards and stocksin-trade. The treasure-hoards bear evidence that there were accumulators of wealth in prehistoric times as to-day. When the objects in the hoard are worn and when new and old are mixed together we 
may conclude that they represent the savings of some prehistoric capitalist, or perhaps miser. When, on the contrary, the objects in the hoard are new, we may regard them as a trader's stock.

Here, if it has not already done so, the question will suggest itself-How is the age of ancient objects arrived at? Are ages and dates assigned arbitrarily and, if not, how are they worked out? Age and date in question are calculated partly on the evidence of things with which discovered objects are found associated, partly on the geological deposit in which they were found and partly on the style of workmanship or ornament as indicating evolution from other types the approximate periods of which are known.

The Bronze Age of Ireland might, with some justification, be called the Age of Gold. An immense number of gold objects belonging to the period and decorated in the peculiar style of the Age has been found in Ireland; indeed, the claim has been made that our National Museum possesses a larger quantity of wrought Bronze Age gold than any museum in Europe. The great Clare "find" of I854 was probably the largest hoard of prehistoric gold ever brought to light in Western Europe. Workmen employed in building the Limerick to Ennis railway were excavating the site of a demolished lios when, beside an old hawthorn bush, they unearthed a stone cist containing a veritable heap of gold in the shape of necklets, bracelets and 
fibulæ. The objects were, unfortunately, seized and scattered before there was time to make even a hurried examination of them; only a few found their way to the Museum. There is some comfort-though it be of rather a chilly kind-in the thought that, far as we know, the "find" yielded no object of unique type or ornament. This Co. Clare find and the great quantity of gold in the national collection corroborate the general claim of our ancient storytellers that Ireland was formerly very rich in the precious metal. There can be little doubt, or none at all, that this gold was of native origin. Neither can there be reasonable doubt that the main supply was from Co. Wicklow. Probably the native supply of raw gold gave out or became considerably reduced towards the end of the Bronze Age. At any rate we do not find gold so much in evidence in the succeeding Early Iron and Christian periods.

Bronze Age objects of gold are usually personal ornaments-of which the best known are the lunula, the gorget, the torque and the fibula, besides gold balls, discs and rings. Lunula, gorget and torque are varieties of the gold necklet. The first is a crescent-shaped collar fastened in front by hooks with which the attenuated ends are furnished. Decoration (a design of chevrons) on surface of the lunula is mostly confined to the tapering ends-a fact which indicates that, when in use, the undecorated surface of the necklet was covered by the 
flowing hair at the back. All available evidence points to Ireland as the lunula's place of origin; the lunula in its distribution is confined to Ireland and the oversea regions which were formerly in close touch with this country. The gorget (Fr.-gorgette, a piece of throat armour) is a horse-shoe shaped gold collar somewhat resembling the lunula, of which, indeed, it may be regarded as a variety. Unlike the lunula, however, the gorget (a) is of uniform width throughout, (b) it terminates at its open ends in great circular discs of gold two or three inches in diameter, and (c) it is decorated with a repoussé ornament of line-and-dot pattern. Much better known than either lunula or gorget is the torque, regarded for over two thousand years as a characteristic personal ornament of the Celts. The torque is simply a flexible plain or twisted rod, or rope, of gold bent into circular form and furnished with terminal hooks for fastening in front. In this connection may be recalled the well-known late Greek figure known as the "Dying Gladiator"; this pseudo-gladiator is a Celt-the earliest of his race known to us in art, and his creator furnished him (considerately enough, lest anyone should miss the point) with the twisted Celtic torque. In this connection, too, the classical student will call to mind the patrician warrior, Titus Manlius, who earned immortal glory and a surname ((Torquatus) by slaying in single combat a gigantic Gaul, whose golden 
necklet he thereupon appropriated. The fibula, most characteristic and familiar of ancient Irish personal ornaments, is an arc or semi-circle of gold, the free ends of which terminate in open cups; it is not flexible, like the torque, nor car. :t have been used as a necklet. Though the object is of so frequent occurrence we do not, strangely enough, know exactly how it was worn. Can it have been to fasten the cloak-the cupped terminals serving as buttons? Almost certainly fibula served at least two or three purposes-personal decoration, as media of exchange, and as advertisements of affluence, like modern watch-chains, etc.

Before we come to treat of Bronze Age Monuments it will be necessary to say something of the art and pottery of the period. Irish ornament may be said to have had its beginnings in the Age now under review. With the Bronze Age came in such regular, if primitive, designs as the chevron, the circle, the lozenge, the concentric, the wavy line and the older, or Agean, spiral. How far, if at all, the motives and designs named are conventionalisations of natural forms is a question which does not now concern us; neither is it of immediate concern whether, or not, the designs were religious, totemic, or magical. During the Bronze Age pottery making, which had seen its crude beginnings in the preceding Age, developed considerably; the burial customs of the later Age, demanding cinerary urns for the 
ashes of its chiefs and great men, must have given quite an impetus to the art. Speaking generally, Bronze Age pottery differs from its predecessor of the earlier period in being better burned, in being of finer and better kneaded clay, in being less clumsily built and, mainly, in the character of its ornament. The chief types of Bronze Age pottery are the burial urn, the food vessel, the drinking cup or beaker (hardly found at all in Ireland), and the so-called incense cup. The first of these is probably the most commonly found; it is usually unearthed in a stone-lined cist during tillage operations or in a sand pit; mostly it is found mouth downwards and covering a small pile of ashes and calcined bones. Cinerary urns vary in height from to to 16 ins. or more, with a diameter across the mouth of about ro ins., and, from base to rim, the outline of the vessel is a swelling curve. In a few instances a smaller earthen vessel of about half a pint capacity is found accompanying the interment and, nearly always, a quantity of white, water-rolled pebbles. To the diminutive pot is commonly given the absurd name of incense cup; on the evidence it looks as if the article were a pigmy food vessel-to hold offerings of meat or drink for the ghosts of the dead, according to the ideas of primitive eschatology. The "food-vessel" is a flat-bottomed bowl of about a quart capacity, no doubt meant, as its name indicates, to hold grain, meal, milk or honey. In the absence of 
boxes or cupboards the vessels were used also to hold personal ornaments and even small metal objects. $\mathrm{Mr}$. Lawlor, an Ulster investigator, has recently found in lios chambers a number of food vessels showing traces of carbon as if they had been used as cooking-pots.

Any account of the Irish Bronze Age would be incomplete without some notice of Newgrange and at least passing reference to the other great monuments of the period. Newgrange is a colossal artificial mound on the north bank of the Boyne between Drogheda and Kells. This spot, quite close to Tara and within sight of that famous hill, was for many pagan centuries a noted burial place of the kings and nobles of Erin. It is known in the ancient literature as the Brugh of the Boyne, and, under that name, there are hundreds of references to it ; it was likewise a place of assembly and the scene of ceremonial games. Among the ancient remains of the region three great tumuli stand conspicuousNewgrange, Dowth and Knowth. These are all similar in appearance, and they stand about a mile apart within sight of one another.

Newgrange is the most interesting and best known of the tumuli; let it serve us as a type in which we can also study the others. Like the Great Pyramid, Newgrange was opened and rifled long ages ago. The explorers of the Irish tombs were the Danes, bent-needless to say-on plunder. What the 


\section{THE BRONZE AGE}

marauders found we shall never know. The Irish feared to meddle with the mound, which they regarded as an abode of the Tuatha-Dé-Danaan and the special sanctuary of one Aonghus Og, a dreaded survivor of that ancient race.

At first sight Newgrange looks a natural hillock, but closer examination shows it to be an artificial mound of loose stones and earth heaped up within a kerb of great boulders, and covering, roughly, an acre or nearly two acres. For nearly two centuries the great mound served as a quarry for the countryside, and hence to-day its height is much less than it once was. Resting upon the kerb-circle is a kind of retaining wall of dry-stone masonry, five or six feet high. Outside this and concentric with it are remains of a great stone circle. An inward curve in the kerbstone circle discloses the entrance to the interior passage. Right before the doorway at present lies a large slab of stone elaborately carved in spirals, lozenges and concentric curves.

The combined interior passage and chambers approximate in plan to a rude Latin cross with a stem or shaft 80 feet long and sharp arms forming two side-chambers. Near the entrance the hallway or passage is 4 feet 9 inches high, and, some distance within, its roof drops so low that the visitor is obliged to crawl for a couple of yards; gradually the height increases to $6 \mathrm{feet}$, and approaching the main chamber the roof rises, on the overlapping principle, 
till it merges in the funnel-shaped dome of the chamber, 20 feet from the floor. He must indeed be an unimaginative Irishman who can stand unmoved beneath that cyclopean dome-older by some two thousand years than the beginnings of Irish history. The roof and chamber and the whole tumulus were as much a thing of mystery in the distant days of King Cormac and St. Patrick as it is to-day. What barbaric visions flit across the visitor's mind-of pagan orgy and savage sacrifice to spirits of air and earth and water ages before Celt or iron had come to break the bloody sway of magic and of horrid heathen rite!

On the floor, in the centre of each recess, stands a rudely hollowed stone basin. What was the purpose of these basins? Almost certainly to accommodate the dead body-for, of course, the purpose of the whole monument is sepulchral. Most likely the body was burnt and only the ashes would be deposited within the tumulus. Each basin is, however, of size enough to hold even an unburnt body if the latter were bent into a contracted position after the manner of primitive interments. At Loughcrew, Co. Meath, where the cairns are in every way similar to Newgrange, the basins contain burnt remains. At the same time it ought to be added that we do not yet know why it is that in some Bronze Age burials the body is found burnt, while in others the skeleton is whole, indicating inhumation. To add to our per- 


\section{THE BRONZE AGE}

plexity we do actually sometimes find burnt and unburnt remains in the same grave.

What is, perhaps, the most remarkable feature of Newgrange remains yet to be noted-the series of barbaric designs with which the faces of the great blocks lining passage and chambers are inscribed. In a few cases the designs are cut in relief, but mostly they are engraved. The most striking motive used is the spiral, sometimes single, at other times double and involved. There are chevrons, likewise, and other motives; also fern and palm leaf patterns, cup-markings, and a so-called ship-marking. Three or four points worthy of further special note are (a) that the engraving is, as a rule, confined to the split surfaces of the stones-the water-bounded faces being uninscribed, (b) that the inscribed blocks increase in frequency as we approach the central chamber, (c) that many of the exposed surfaces are picked over by a metal tool, and (d) that often the ornament extends to the inturned sides of the stones, where manifestly it could never be seen and where no tool could have reached it.

M. L'Abbé Breuil, the foremost European authority on prehistoric art, has recently visited Ireland and made a study of the Bronze Age inscriptions of this country. As a result of his personal examination of the monuments the distinguished scholar has formed the opinion that the Irish carvings are not, as we had believed, all of the same style and period; 
he distinguished, for example, at Newgrange, two styles, and clear evidence of superposition of a later ufon an earlier. He is also of opinion that our Irish petroglyphs, while showing no direct evidence of Minoan parentage, have distinct analogies with Spanish and Breton rather than with Scandinavian examples. ${ }^{1}$

$$
\text { 1. Proceedings R.I.A., Aug., } 1921 .
$$




\section{CHAPTER III.}

THE EARLY IRON AGE.

No Irish prehistoric period has received so little attention from native writers as the Early Iron Age, which began in this country about the middle of the fourth century B.C. and ended in the fourth century after Christ. Apparent neglect of the period is due, perhaps, to its comparatively short duration; but an era's importance is not to be measured by its length. As a matter of fact, the Early Iron Age is an age of transcending importance to the Irish archæologist; it witnessed the discovery, invention or introduction of ogham writing; the growth and development of new artistic notions, the first use of enamel, the socalled Milesian invasion, the rise of Tara to political pre-eminence, and finally, and most important of all-the substitution of iron for bronze in military weapons and in implements of husbandry. The Early Iron Age, it is now clear, saw much movement of populations within the Celtic world. Although, throughout the early centuries of the age, peoples are on the move in Western Europe, we 
cannot see as clearly as we should wish what were the racial changes effected. We seem to hear, as it were, from a distance, or from behind a wall, the tramp of marching multitudes, but what all the movement means we cannot with any certitude discover. The student must in this connection remember that the age would be appreciably later in Ireland than on the Continent, and later in Western than in Eastern Europe. In the $A$ gean its beginnings are as early as the Trojan War ( 1184 B.C.), and even in Middle Europe its earliest, or Halstatt, period would go back to about the ninth century B.C. Again, he must bear in mind that the introduction of iron would not, and did not, bring about the immediate disappearance of bronze, any more than the discovery of bronze, two thousand years earlier, brought in its train the immediate disappearance of stone. Bronze, in fact, never went entirely out of use, though, of necessity, it sank to a secondary importance on the discovery of iron and was relegated thereafter to the manufacture of ornamental, or ceremonial, rather than of utilitarian, objects.

As history had not yet begun, we cannot look to it for any record of the changes which the discovery of iron must have brought about in the lives of men. Archæology, however, furnishes us with a little light on the subject. We are all familiar with some of the popular superstitions regarding iron. Horse-shoes are nailed for good-luck over the cottage door-way, 


\section{THE EARLY IRON AGE}

or perhaps in the middle-class drawingroom. The writer remembers being taught when a boy that it was a lucky thing to find a piece of iron. The machinations of witches and other evil-working pisioga are counteracted by the virtue latent in a heated ploughshare. Persons who see ghosts dispel the vision by touching iron. In these, and in many other superstitions, folklorists recognise echoes, traditions and memorials of a time when iron first came in to dispel the terrors of Bronze Age magic.

Our Early Iron Age is very generally referred to in the works of English authorities as Late Celtic. Some Irish scholars, too, have adopted this name, which I cannot help thinking unfortunate and misleading. Applied to the Early Iron Age of Britain the designation may be correct enough, but applied to the corresponding Irish period it is a misnomer. The reason is that Ireland had a later "Late Celtic" -the Early Christian period. To this latter, therefore, the name, if it be used at all at this side of the Irish Sea, ought to be given and confined.

An extensive prehistoric cemetery at Halstatt in Upper Austria affords us our earliest evidence of that limited period of transition from bronze to iron. The grave furniture at Halstatt is of mixed bronze and iron, indicative of the overlap. The people buried here were the early workers of the salt mines which gave its name to Saltzburg; they were not yet 
called Celts, but they were of the race which became known as Celts some centuries later. Similarly, their art, if not Celtic, was the parent of what under La Tène influence, four or five centuries later became "Celtic" art. Professor Ridgway, by the way, seems inclined to identify Halstattians with the Achæans of Homer.

The art and artistic motives of the Celtic Early Iron Age marks a decided advance on the art of the preceding period. For the chevrons, lozenges, and other geometrical motives of the Bronze Age there is substituted an almost endless variety of free and graceful curvings, highly pleasing to the eye, though hard to describe in words. Let the student look at the picture of the Turoe (Co. Galway) Stone, the Broighter (Co. Londonderry) Collar, the Lisnacroghera (Co. Antrim) sword-sheaths, or the Blackrock (Cork) bronze cones, and he will understand what I mean. It can, I think, be fairly claimed that in beauty of design and graceful finish the art of the Early Iron Age has seldom or never been surpassed.

It is usual to distinguish two sub-periods of the Early Iron Age-an earlier and a later, or, as they are more generally called, the respective eras of $\mathrm{Hal}$ statt and La Tène. Each of the sub-periods is again sub-divided-one into two and the other into three epochs. Between the sub-periods, as between the epochs, there is no boldly-defined line of demarcation: the contiguous eras fuse into one an- 


\section{THE EARLY IRON AGE}

other as day into night or as the colours in the rainbow.

The La Tène sub-period gets its name from a prehistoric settlement, or rather a military post and customs-house of the Celts, which was situated at the north end of Neuchatel Lake on one of the great prehistoric trade routes. La Tène was first explored in 1856 , when the waters of the lake were lowered by drainage. Recently the site has been systematically investigated by the Swiss Government-with results most interesting and valuable. The objects of interest found were largely weapons of war, which in their character and ornament illustrate a period some centuries later than Halstatt.

Though occasional objects of Halstatt style reached the British Islands, by way of commerce or foray, it must be confessed that the influence of the first Early Iron Age sub-period on this country was but slight. Its art motives do not appear to have affected Irish craftsmanship in any degree. Indeed, it is not till mid-La Tène, or thereabouts, that we actually find the new culture acclimatised on Irish soil. The surviving examples of La Tène art in Ireland are, however, comparatively few-so few as to suggest the objection that they were of foreign, and not native, workmanship. The Turoe Stone, at any rate, weighing several tons, cannot have been brought overseas.

I have already enumerated our principal Early Iron 
Age monuments; they will bear a brief description. The Turoe Stone is a large block of granite, four feet high, which stands in the lawn of Turoe House, near Loughrea. This, however, is not its original position; it was found about eighty years since in a neighbouring lios, whence it was removed to the present site. A beautiful design of mixed foliage and geometrical motive covers the upper portion of the stone, while around its middle runs a belt of Greek fret - the angular pattern of which affords a strong contrast to the curvilinear work above it. There is a fine cast of the stone in the National Museum. At a place called Castle Strange, Co. Roscommon, is a similar, but smaller, monument, with inferior carving. The Broighter Collar is the most magnificent example of LaTène work yet found in these islands. This is in the form of a hollow tube of gold, $7 \frac{1}{2}$ inches in diameter, with a bore of $1 \frac{1}{2}$ inches. The tube is of two gold plates, rolled and soldered together and ornamented alike. Bold, graceful curves with trumpet-mouth expansions are the most prominent element in the design ; these form a continuous pattern. The Lisnacroghera sword sheaths (2) were found with many important objects in a Co. Antrim crannog. Here again the decoration is of singular elegance: the pattern is a series of involved $C$ curves, and the lines of the design are double, the interstice being intended for an enamel inset. The bronze cones from Blackrock, Co. Cork, are three in number, about one foot each in 


\section{THE EARLY IRON AGE}

height, with La Tène ornament near the bases. There can be little doubt that the three cones once formed portion of a head-dress.

Any account of the Early Iron Age period would be incomplete without notice of the Ogham, that ancient system of writing which had its origin in this age, although its surviving monuments belong to a somewhat later time. The Ogham seems to have been peculiar to the Celts of Ireland, and possiblynay, probably-it was of Irish origin. The exact connection, if any, between the Irish Oghams and the Scandinavian Runes remains to be determined. For the study of Celtic philology, as Sir John Rhys remarks, the importance of the Ogham is equivalent to the importance of Roman inscriptions in the supposition that all other remains of Roman speech had utterly disappeared. Older, by centuries, than St. Gall or Wurtzburg Codex, the Ogham inscriptions give us the most early ascertainable forms of Celtic words and inflections.

The modern history of Ogham study is a very curious record indeed. The fathers of scientific Irish archæology had but little respect for the Oghams; investigators of the latter they seem to have looked upon as charlatans of the Vallancey school; the ancient script itself they wrote and spoke about as if it were something utterly unworthy the attention of scholars. Now, they seem to have deemed the inscriptions as meaningless scores; again, they refer to them as 
modern forgeries. O'Donovan was, strange to say, probably the most sceptical of all, though surely one would have thought the Ogham tract in the Book of Ballymote ought have brought home to him that the archaic script had a serious purpose. It is not easy to-day to justify, or even understand, our premier Irish scholar's position; on the other hand it is, of course, very easy for us to be wise after the event. I believe O'Donovan's quasi-hostility to Ogham study was mainly due to the flavour of Vallanceyism which characterised the pursuit in the beginning. A number of pseudo-scholars of the old school had taken up the subject and were advertising themselves and publishing the most astounding and impossible discoveries and deductions. A concrete instance will best give an idea of the kind of thing which passed for Ogham interpretation seventy years since, in the balmy days of the South Munster Antiquarian School. Mr. Fitzgerald, of Youghal, found an Ogham-inscribed stone set in the gable of St. Declan's Oratory at Ardmore. The finder carefully copied the scores, of which he forwarded transcriptions to some of the amateur archæologists of the day - to John Windele, of Cork, for example, to Professor Connellan of the Queen's College, to Father Matt. Horgan of Blarney, etc. Subsequent posts brought $\mathrm{Mr}$. Fitzgerald some extraordinary replies and strange and varied readings of his Ogham legend. I may say that the latter almost certainly reads : 


\section{THE EARLY IRON AGE}

Lugudeccas Maqi Mucoi Neta Segamonas.

Dr. Petrie observed:- "I utterly deny that the lines on the stone at Ardmore are a literary inscription of any kind." Father Casey, P.P., of Killarney, one of the pseudo-authorities of the time, rendered it: "Here lies Goll the renowned sorcerer." A third correspondent replied: "The Oghams are tricks of the Middle Ages and will soon be exposed." Yet another enthusiasi-Father Horgan, I think-read it as commemorative of an individual described as "the swift and the brave.". Still another rendering was added by, I imagine, Mr. Fitzgerald himself, scil.: " Lughud was a horseman on the field of battle" !

At the same time we owe a great deal to the labours of these early investigators; with all their absurdities and, notwithstanding their blunders, these devoted workers did much real service to Irish archæology; they hunted out inscriptions; they prevented the destruction of monuments; they effectively called attention to Irish epigraphy. In this connection I may relate that at that time, more than half a century since, when Ogham-hunting was the vogue in Munster and when Windele and his co-labourers were giving rewards for reports of new inscriptions, what promised to be a new industry sprang up in parts of Cork and Kerry, scil.: the manufacture of ancient inscriptions. One wicked old man cut a neat Ogham on a likely-looking piece of sandstone which he 
buried for a while in his garden to age it. Disinterring it later, he kept it under lock and key in his bedroom, producing it from time to time for a fee to the inspection of scholars!

Robert Rolt Brash, architect, of Cork, may be regarded as the first really scientific student of the Ogham. His work, "The Ogham-inscribed Monuments of the Gaedhil," is now somewhat out of date and it is easy to belittle its value. It was, however, a great work for its time, and even to-day it has very considerable value, and second-hand copies fetch a good price. The work commenced by Brash was continued by a fine scholar, Rev. Charles Graves, afterwards Protestant Bishop of Limerick. Dr. Graves devoted the best years of his life to Ogham study, contributing numerous papers thereon to the Royal Irish Academy publications. Bishop Graves had a special faculty for solving knotty inscriptions. Unfortunately, however, he did not know old Irish-an ignorance which hampered and hindered him at every step. Rev. Edmund Barry, P.P., of Rathgormac, County Cork, commenced the study of Oghams rather late in his life. He was, however, an indefatigable worker, and he managed in a short time to secure some very valuable results. At a place called Ballyknock, not far from the boundary of his own parish, he discovered in a souterrain the largest cache of inscriptions yet unearthed in Ireland. Father Barry left no formal work on his subject, but he contri- 
buted many papers on isolated inscriptions to various antiquarian journals. He had a volume in preparation which remained unfinished at his death. This, with some allied MS. matter, he bequeathed to the present writer, who, at one time contemplated publishing the Ogham tract, in Father Barry's memory. Meantime, however, the first part of Professor Macalister's "Studies in Irish Epigraphy," appeared, rendering Father Barry's work superfluous. Other noted workers in the field of Irish epigraphics have been Sir Samuel Ferguson, Dr. Whitely Stokes, and Professor Sir John Rhys, who. brought to bear on their subject great philological knowledge and experience. Lastly, I must mention and pay special tribute to the splendid labours of Professors Macalister and MacNeill, who, between them, have effectually succeeded in dispelling almost all the mystery which long had enveloped the Ogham.

Looking at the Ogham inscriptions in the light of modern knowledge, we may not find it quite easy at first sight to understand how they could, at any time, have presented much difficulty. With our present keys and experience, decipherment and interpretation involve comparatively little labour. The knowledge, however, which we now possess has had to be built up slowly and with immense patience and toil. Similarly, many problems of Celtic archæology are today being laboriously worked out, and no doubt there will be some who come after us who will think how 
very dense we were not to have seen much which to them will be then so obvious.

What is this Ogham writing? What literature, if any, does it enshrine? What is its origin, its history, its character, and its geographical distribution? Lastly, are there any data from which we can approximately infer the periods of its invention, development, extended use and decay? These are the questions to which we shall next address ourselves.

The Ogham is not, as some of my readers may have thought, a language, dialect, or even literary jargon, but an a'phabet or cypher-a cumbrous and clumsy alphabet, which might by modification be adapted to any language. As actually developed and used, this curious script was accommodated to the sounds of the oldest known literary form of Old Irish.

The Ogham alphabet consists ordinarily of some twenty signs, which take the form of scores or notches - generally on the edge or arris of an undressed standing stone. I say ordinarily because the MSS. reckon many additional symbols very few of which we find in surviving Ogham texts.

Next, let us study the ogham key as furnished by the Book of Ballymote :-

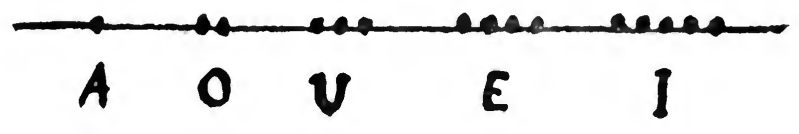




\section{THE EARLY IRON AGE

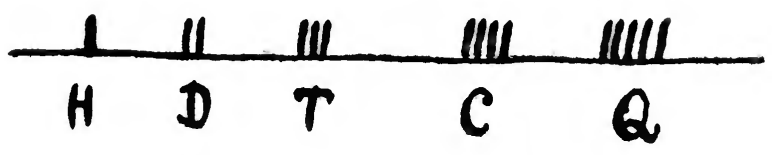

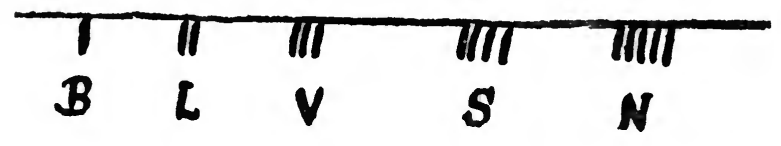
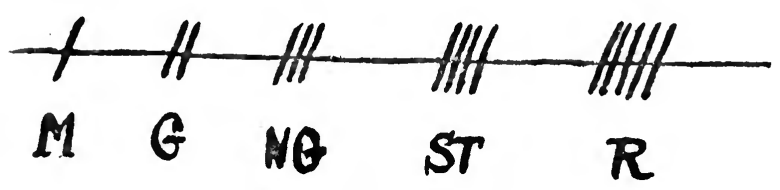

We notice (I) that its inventor, who had some scientific knowledge of orthography and orthoepy, distinguished very clearly between the respective functions of vowels and consonants. The vowels are mere notches on the edge of the stone while the consonants are deeply cut long strokes. We observe (2) that the vowels are associated into broads and slenders, and (3) that some sounds for which we have signs in English (there is no $p$, for example, and no $f$, and the sound of $z$ is represented by st.) are unrepresented. It can be shown that our Ogham alphabet is based on the Latin, a fact which is of importance in estimating the period at which the former was invented. Two of the symbols given above, scil: $-h$ 
and $s t$ have not yet been found in any recorded inscription. Another symbol-the third of the third line-is sometimes styled $f$ rather than $v$, because at the time the Book of Ballymote was written ancient Indo-European $v$ had become $f$. Compare the Latin vir with the modern Irish fear. Philology is able to establish that the sound of $f$ was $v$ at the Ogham period.

In practice the vowels are more difficult to read than the consonants; being mere notches, the former are sometimes almost impossible to detect; not infrequently they have disappeared altogether. What, by the way, is the Oghamist to do where one or more of his scores have been erased? He must try to calculate the value of the missing strokes from his context or from the average distance separating the scores; for example, he finds one vowel mark followed by a spawled or worn space of sufficient length to accommodate three vowel marks extra, and he calculates that the partly missing letter was $e$. The vast majority of Ogham words are personal names, and the same, or similar, forms occur again and again. It is therefore oftentimes quite easy, having got some letters of a name, to restore the rest conjecturally; as if in a modern graveyard I find, for instance, on a worn tombstone, the letter $P$ followed by a blank space sufficient for five letters, and then the letter $k$, I naturally conclude that Patrick was the Christian name of the dead man commemorated. 
I have stated that, in addition to the symbols found in our surviving Ogham inscriptions, the prehistoric writers used a number of others. These latter do not immediately concern us. A symbol identical with our sign of multiplication, however, claims a few words of notice. This is found in sixteen inscriptions, in four of which it is almost certainly a vowel and in the others almost necessarily a consonant. When a vowel the sign is equivalent to $E$, and when a consonant Professor Macalister has shown that it is $C$. In one instance the $x$ is found to right of the line or edge. To this Macalister assigned the value of $P$, but MacNeill thinks it is still $C$. As the Ogham literati had already an $E$ and a $C$ it is not clear why they introduced an overlapping form. I suggest that the introduction in question had something to do with guarding against ambiguity; the ordinary sign for $E$ is liable to be read $A U$ or $O O$ as the ordinary symbol for $C$ is liable to be taken for $D D$.

Ogham literature (as distinct from literature of the ogham) is tantalisingly meagre. Considering the number of inscriptions, it is wonderful how little they tell us. The legend, when not so terse as to be unintelligible, contains the name of the deceased merely, with, at most, the name of his father and the name of his eponymous ancestor, for instance:-

Cumni Maqi Mucoi Valuvi

(Of Cumnos the Son of Valufos). 


\section{PREHISTORIC IRELAND}

The first word of the inscription is generally in the genitive case, as if the term-stone, monument, or memorial, were left understood. We know now, however, that the word to be understood is not monument, etc., but anm, name. In a very few instances the first noun is in the nominative case. Extraordinary as the use of the genitive in such a connection may appear, it will seem still more extraordinary to have the name (as it is found in a few instances) in the dative. Students of Irish toponomy will perhaps recall that, in a somewhat similar fashion, some of our place names are in the dative case. In quite a large number of inscriptions, parentage of the person commemorated is signified by use of the word Maqi, "Son (of)." Occasionally inigna, " daughter (of)" is found, and, in a few instances, avi, "grandson."

Geographical distribution of the Ogham inscriptions is commonly regarded as proof, at least presumptive, that the script was invented in Ireland. Why? Because the vast majority of the inscriptions have been found in this country and the remainder come from lands at one time in close touch with ancient Ireland. It may, of course, be objected to this argument for Irish origin of the Ogham that the inscriptions survived in Ireland and the parts adjacent just because the Irish wrote on stone while their neighbours used a less lasting material. A few alleged Oghams have been reported from the Continent-from Saxony, but 
these, if they be really Oghams, are in a language, if it be really a language, other than Irish.

The limited geographical range of the Ogham has been already alluded to. That range is practically confined to portions of Ireland and Wales, and to a particular area in Scotland. Five-sixths of the known inscriptions have been reported from Ireland, and of these the great majority belong to the South-West, viz. : to the Counties of Kerry, Cork and Waterford. Here are the exact, or approximately exact, figures :-

Total number of recorded inscriptions $\ldots 36 \mathrm{r}$

Total number found in Ireland ... $\quad \ldots \quad 301$

Total number found in Co. Kerry $\quad \ldots \quad$ I 20

Total number found in Co. Cork ... $\quad \ldots \quad 8 \mathrm{I}$

Total number found in Co. Waterford ... 40

This gives a total of $24 \mathrm{I}$ inscriptions from the three counties as against 59 for the rest of Ireland. In the rest of Ireland, except the Counties of Meath and Ossory, inscriptions occur only sporadically and there are some seven or eight counties in which no Ogham has so far been found. N.-E. Scotland has yielded I6 examples-all from the Pictish region. In Wales 26 inscriptions have been discovered; in the Isle of Man, 6, and in the S.-W. of England, 6. As has been already stated, some inscriptions have been reported from Saxony, and it has been suggested that they are the work of some wandering Gael of the olden days who knew just a smattering of the Ogham. 
All the inscriptions from the British Isles are in an early form of Irish-except a very few from Scotland, which are said to be in Pictish.

Next we come to the date, or period, of the inscriptions. By the older antiquarians the Oghams were, almost universally, regarded as of Pagan origin and character. The presence, on many stones, of an incised cross sometimes occasioned doubt, but the Christian symbol was explained as merely significant of a later re-dedication. Half a score or so of years since, convincing arguments-all philological-were brought forward in favour of a $5^{\text {th }}$ or 6th century (and, therefore, a Christian) origin. It was shown that the actual forms, etc., of the names were those which, according to the laws of Indo-European philology, the words should bear in the $5^{\text {th }}$ or 6 th century of our era. Being of the Christian period, it was naturally assumed that the inscriptions were the work of Christians. Now, however, comes Professor MacNeill contending (at any rate by implication) that the bulk of the Oghams are Pagan. While admitting that they are of the Christian period, the Professor argues that the cult must have been in the hands of Pagans, for (a) the inscriptions do not show the characteristic Christian nomenclature; (b) no known Ogham expresses anything of Christian belief or feeling, and $(c)$ the present distribution of the Ogham indicates an arrested custom, the cause of the arrest being Christianity and spread of the Latin alphabet. 


\section{THE EARLY IRON AGE}

As sustaining the Pagan theory, I may here mention a very curious fact noted by Macalister :-in Kerry a large proportion of the mucoi texts are defaced, and evidently by design. The word following mucoi is carefully obliterated. What are we to infer from this? Clearly there was something objectionable in this portion of the inscription. What can it have been? Simply this:-the word immediately following mucoi was the name of the eponymous (i.e., name-giving) ancestor, and this latter was often a Pagan deity. Hence the hostility of Christianity to that style of inscription. Certainly the contrast in character between our earliest Christian, and the Ogham, inscriptions is very marked. On the avowedly early Christian monuments we find the word Oráid, or the formula Oráid air anmain; in the Ogham there is nothing of prayer, or immortality, or of hope beyond the grave. To be sure, as we have seen, some of the monuments are cross-inscribed, but this is no valid argument against the Pagan origin of the inscriptions unless we can show (which we cannot) that inscription and cross are contemporaneous. The hostile force, whatever it was, which defaced the inscription, would also account for incision of the cross. Corroboration of what I may call the Christian-period theory is furnished by the fact that Oghams are generally found in cillins (early church sites) or in connection with the latter. When inscribed stones are found, as at Drumlohan or Ballyknock, built into souterrains, 
etc., it is pretty evident that the monuments had already served their primary purpose before their removal for insertion in the rath chamber, and, in many instances, the chamber in question is close to a cillin. On a summary of the evidence I think we may safely conclude that the Oghams, whether they commemorate Pagans or Christians, were cut by men with Paganising tendencies. This Pagan flavour of the Ogham is moreover suggested by the ancient literature which uniformly refers to the ancient script as of Pagan association.

It, by no means, follows from the late date of the surviving inscriptions that the Ogham was not also in use in the Pagan centuries. From references in our ancient books it is evident that, for purposes of correspondence, etc., the Ogham scores were cut on a stick or rod or on a series of rods. An Ogham message incised on a bundle of willow rods could be carried forty or fifty miles by a fleet-footed runner in a single day. In the Táin Bó, Cuchullain is represented as communicating by means of Ogham messages with Queen Maeve; the scores were read and interpreted to the Queen by a secretary or Ogham expert whom she had in her train.

Here the question arises of the period at which the Ogham was invented. Granting that the bulk of the inscriptions date from the early Christian centuries, have we any means of gauging the beginnings of the craft? Professor MacNeill suggests what appears 
a satisfactory method. The period of invention, the Professor argues, must be subsequent to the Roman invasion of Gaul and some time previous to the Early Classic period (close of Ist century A.D.). First, it must be some time later than the conquest of Gaul, because up to that event the Celts had been using the Greek, and not the Roman, alphabet, and the Ogham, as we have seen, is based on the latter and not on the former of these. Secondly, it must be before the introduction into Latin of signs to represent Greek sounds. These signs were introduced into Latin in the Augustan age, and, as there is nothing corresponding to them in Ogham, we conclude the Oghamic system was perfected before their introduction. We thus arrive at the Christian era as the approximate period of invention; perhaps we ought say a century or so later than the Christian era - to allow for filtration of knowledge to our distant island of the West. The Ogham will thus have flourished during some four centuries. The intelligent reader will understand that this is only a tentative, or provisional, statement. We must await further investigation and fuller evidence before we can speak quite positively. Although the Ogham lived into Christian times it appears to have remained Pagan, at any rate in association, to the end. It was not only, as MacNeill observes, that Christianity, with its Roman alphabet, had no use for it; it moreover shunned the Ogham as a Pagan cult, and not a 
scrap of Ogham beyond the bare alphabet was allowed to survive in the MSS.

Perhaps all this time someone has been thinkingwhy all this bother about the reading of Ogham inscriptions? If the scores have really the value ascribed to them, where is the difficulty? In reply let me remind my reader that the Ogham monument is of enormous antiquity, that it has stood exposed to the rains and snows of fifteen hundred winters, that chemical action has worn and smoothed its surface, and that grey lichen has eaten into it; cattle probably have used the pillar as a scratching post, and irreverent youths have flung stones at it, and knocked off splinters. Consequently, in many cases, exact determination of the scores is impossible, though absence of a single score may completely change the value of a letter. It requires experience, together with minute examination and power of careful observation, to make a successful reader of Oghams. Suppose the scores clearly defined, and their number certain, another difficulty may now confront the investigator. How is he to read the legend-up or down? Inscriptions generally read upwards, and from left to right, but sometimes they run in the opposite direction, and occasionally the position of the pillar has been reversed! You will suggest: read the inscription in the way it makes sense. But suppose it makes sense of a kind both ways? 


\section{THE EARLY IRON AGE}

In practice we first look for the key word, which is $M a q i$, and, having found that, we note the direction in which it runs, and read our scores accordingly. To bring out the scores more distinctly we rub the inscribed angle with a wisp of green grass; this has the effect of giving the scores a kind of relief, which greatly helps the reader. If we cannot make sense of our reading, and if we wish to take away a copy of the inscription for future study, we make what is called "a rubbing." We get a sheet of fairly soft white paper such as is used in creameries to wrap butter in; we lay this carefully over the inscription, and rub it gently along the exposed surface with a bunch of green grass or a piece of heel-ball, and if we do our work well, we shall secure an excellent impression-every whit as clear (or as far from clear) as the original. 



\section{CHAPTER IV.}

\section{ANCIENT IRISH RELIGION.}

WE know very little that is certain of ancient Irish religion, and the little we do know we deduce largely from our limited knowledge of Gaulish paganism before this latter was affected by Roman influences. As our knowledge of Gaulish heathenism is scant, it follows that our knowledge inferred thence of an allied religious cult must be scantier still. Notwithstanding all this, we have a surprisingly copious modern literature on the subject-a literature far too much distinguished by vagueness, uncertainty, and speculation. Accounts of human, and other, sacrifices by druid priests, in sacred groves and roofless temples, rest on little solid foundation, for of the bloody rites in question, and of the groves and temples, we have only the flimsiest evidence. This paucity of evidence regarding the tenets and practices of Irish heathenism may strike the reader as curious. The explanation is, however, both complete and easy. For a century or two, from the time of 
Patrick, the early Church of Ireland was engaged with all her might in a hand-to-hand fight against paganism, and even at the end of two centuries all traces of the ancient cult had not been wiped out. In course of this struggle there was, almost necessarily, widespread destruction and mutilation of documents, and the Christian censor only ceased his work when he had eliminated from the pagan literature everything that savoured of the old religion. We could now well wish that the censor's hand had been less heavy, and that his eye had been less keen, or even that he had been somewhat less conscientious in his task. Regret it, however, as we may, the destruction of evidence is complete, and it is only indirectly-reading, as it were, between the lines of the venerable pages-that we are able, in the MSS., to catch a few fitful messages from the prehistoric past.

Dearth of material is not the only difficulty with which the student of early Irish religion has to contend. Another is that he has here to deal, not with a single defunct religion, the Celtic, but with a second, the pre-Celtic, as well. How shall he distinguish their respective stratifications, how unravel the very complex story of their inter-relationships, their comminglings, and their mutual borrowings? In Ireland, and in Gaul also, the religious belief and practices of the conquerors would be-necessarily, I might almost 


\section{ANCIENT IRISH RELIGION}

say-affected by the religion of the aboriginal population. How far syncretism, or a fusion of the two faiths, took place we cannot at present correctly gauge.

The evidence to be derived from primitive burials does not help us very much in our study of ancient Irish worship; it proves little more than that our pagan progenitor believed in a life to come; his tomb was supplied with certain grave furniture for the dead man's comfort in the world beyond the grave. Temple buildings, if we had them, might give us many a clue to the supernatural beliefs of their builders; we have, however, in Ireland no temples which we can recognise as such. Rude stone monuments, to be sure, survive in abundance, but that they had to do with worship has not, so far, been satisfactorily demonstrated. At the same time it is probable that many of these latter monuments had a religious purpose. Ancient personal and local names shed some further faint light on our subject and the incidental remarks of classical writers more light still, but it is the votive inscriptions of Celtic Gaul which constitute, perhaps, our most reliable source of information. These inscriptions, generally attached to altars or sanctuaries, are incised on stone-usually an oblong marble block, say a couple of feet long by one foot and a half wide. The inscription, in contracted Latin and not always easy to read, denotes dedication to a pagan god, and the point is that, while the formal dedication is to a 
Roman deity, the latter is equated or identified with some Celtic divinity whom he, or she, is supposed to resemble in character or attributes. These inscriptions, which are very numerous, give us such a series of names and equations as enables us to reconstruct to a certain extent a Gaulish pantheon. It was, probably, the break-up of native Celtic traditions under the blighting influence of Roman culture which introduced the votive-tablet fashion into Gaul. Roman culture and domination tended to a fusion or overlapping of deities originally independent. It is pretty evident that the dedications are, as a rule, the work of pious Roman soldiers and colonists; if any were erected by Gaulish natives we can conceive the latter as Celts of Romanising (or shall I style it-West-Briton) tendencies. It is not alone with Gaulish gods that the Romans equated theirs. We know from their history that the ancient rulers of the world acted similarly in the case of other conquered peoples. In Palestine, for example, a pious citizen of the empire identified his own Hercules with the Hebrew Jehovah. In the Gaulish inscriptions, with which we are immediately concerned, the Roman name of the god is given as his appellation, with the Gaulish name appended as a qualifying designation or sobriquet, thus-Mars-Caturix, Apollo-Grannus, Mercury-Esus, etc. Caturix, Grannus and Esus are here the Gallic deities regarded, as in some degree identical, respectively, with the Roman gods, Mars, Apollo and Mer- 
cury. As, however, the gods of the Celts seem to have been far more numerous than the Roman gods, it often happens that a single Roman god has to be equated with two or three, or even ten, Gallic godsunder one aspect of his character with one, under another with a second, and so on. The great number of Gallic deities is explained, in some degree, at any rate, by the fact that the Gauls seem to have lacked universal deities, and that instead they had allotted to each important natural feature (glen, river, hill, and waterfall) its own special guardian spirit or local god. There are a couple of Gallic gods, not equated with any corresponding Roman deities, whose effigies, and even names, have been found. One of these is Cernunnos, who possesses some special interest for us, inasmuch as Professor Macalister believes he has discovered his figure at Tara-carved in relief on the stone known as the Cross of Adamnan. The god in question is represented sitting cross-legged, and as wearing a heavy torque around his neck and horns on his head.

The references thereto of Roman writers do not give us at all as much light on Celtic religion as we should desire, or as, perhaps, we might expect. We can understand how difficult it is for one people to grasp the religious tenets, views, or points of view of an alien race. There is the natural reluctance, on the one side, to talk with a stranger on matters so 
sacred; there is, on the other hand, the tendency of the conqueror to regard the religion of the conquered as something unworthy of serious attention. The Romans had a fine conceit of themselves and their culture. All the world, outside themselves, was barbarian, and the barbarian's notions mattered little. The barbarian's manners and customs, his culture, philosophy and religion, excited only the mildest curiosity-that is, when they did not excite contempt. This fact renders of reduced value the testimony of classical writers regarding the war-loving and restless Celts.

Casar, who came into closer touch with the Celts than anyone else of his nation, thus sums up his study of their religion : " Most of all they (the Gauls) worship Mercury, of whom they have many images; they consider him the inventor of arts, the patron of travellers and the strongest in matters relating to business and commerce. After him they worship Apollo, Mars, Jupiter and Minerva, about whom they have much the same beliefs as other nations-such as that Apollo drives away diseases, Minerva teaches the elements of industry and the arts, Jupiter rules the sky, Mars directs wars. When they have decided to engage in battle they usually vow to Mars all the spoils taken in war, so they sacrifice to him all the animals captured and bring the rest of the booty together in one spot." We may use this passage of the Commentaries as a kind of text from which 


\section{ANCIENT IRISH RELIGION}

to draw some general conclusions on Celtic mythology.

First, the Gauls chiefly honoured Mercury. This statement of the Roman general is in remarkable harmony with the fact that a surprisingly large number of Gallic place-names incorporates the name of Mercury. Montmartre ("Mercury's Mount") is one of them; Puy de Dome is another. On the summit of Puy de Dome are the remains of a great temple within which was found an inscription recording dedication of the hill to Mercury under the Gaulish appellation of Dumiates, and here there is said to have formerly stood a gigantic statue of the Roman deity. Dumiates, whose name survives in Dome, was really a Celtic divinity regarded as, in some degree, equatible, or equivalent, to the Roman. Another divinity similarly equatible, or identifiable, is, according to Lucan and his scholiast, the Celtic Teutates, and yet another, Esus. In fact, the number of Celtic gods identified with Mercury is very large-eighteen or twenty at the least:: also the number of votive inscriptions to Mercury, under one or another appellative-Roman or Gaulish-is immense. An analysis of the equations shows that nearly all the Celtic equivalents are obscure local divinities or genii locorum. The general deduction is inevitable-that amongst the Celts there was no formally recognised universal or supreme god, but an immense number of minor deities with strictly local cults, and that in 
course of time many of these merely local gods became merged, or fused, into one. As two Gaulish deities, or more, are equated or identified with a single Roman god, so occasionally we find one Gaulish god equated with more than one Roman-thus, Esus, abovementioned, equates not only with Mercury, but also with another, and little-known, Roman god-Silvanus. Another equation of Mercury's is with the remarkable Celtic divinity, Ogmios, whom we cannot help identifying with the Milesian Ogma, the reputed inventor of the Ogham alphabet and script. Of this Ogmios and his attributes there is a suggestive tale told by Lucian, a Greek writer of the second century. Lucian states that amongst the Celts Ogmios was represented as an extremely old manbald, bronzed and wrinkled, and carrying a club like Hercules. Also he was arrayed in the Herculean lion's skin. Somewhere in the land of the Celts Lucian saw an effigy of the god-in whom he recognised his own national dejty, Hermes. The eftigy, however, angered Lucian, because he considered it irreverent. The god was represented as having fastened to his tongue slender golden cords, the other ends of which were attached to the ears of a multitude of men, whom, by means of the cords, he drew unresistingly after him. A Celt, who spotie Greek, explained to Lucian that Ogmios is the Celtic god of eloquence, and that he is arrayed as Hercules rather 
than as Hermes to emphasise the power of eloquence over men.

If we are to believe Cresar, the Gauls honoured Apollo next after Mercury. With whom did they equate him? Apollo is identified with quite a large number of Celtic divinities whose attributes are solar emanations (light and heat), and the cure of diseases. There is a close connection of Apollo worship with healing and hot springs. Among the Celtic divinities with whom Apollo is identified or equated two stand rather conspicuous, viz., Belenos and Grannus, both of whom, it is obvious, are of solar connection. The association of Grannus with healing is commemorated in his close relation with the hot baths of Aix-laChapelle, known to the Romans as Aqua Granni. Both Belenos and Grannus had a cultus of fairly wide distribution. How, by the way, explain the relatively extended cultus of gods like Belenos, Grannus and Esus as against the rigidly local veneration of Celtic gods generally? The explanation commonly given is that when the Celtic wave rolled in to Western Europe it found that preceding aboriginal races had already peopled all striking natural features (mountains, waterfalls, lakes, etc.) with guardian spirits. The newcomers learned the names of these beings from the conquered peoples, and promptly adopted them into their own pantheon; their own ancient tribal divinities became the deities of more extended veneration, and the newly-adopted guardian spirits of 
glens and fountains-the purely local gods. This syncretism explains the otherwise unintelligible coexistence of general and local gods, also it explains the mystery of gods with Celtic and gods with nonCeltic names. We are fully justified in assuming that Irish heathenism, which Patrick fought at Tara and through the provinces, was really an alloy, not more than five centuries old, of the Celtic and aboriginalIrish religions.

Mars, the next god enumerated by Cæsar, we find equated-as indeed we should expect, from the warlike and turbulent character of the Celts-with a whole host of local deities, continental and insular. The total number or equated local deities is probably not fewer than seventy. One of them, Segomos, deserves a special note. His name occurs in an inscription from the south-east of France (frontiers of Italy and Switzerland), and we do not meet it again till we come to Ireland where we find it in three Ogham inscriptions from Co. Waterford. Cæsar says of the Gallic Mars that he has the direction of wars, that all spoils are dedicated to him, and that in many of the Celtic cities there are piles of booty sacred to him which no one is irreverent enough to touch.

Jupiter comes a poor fourth in Cæsar's list. It is clear there was no official head of the Celtic heaven - no deity conspicuous enough to claim equation with the father of Roman gods. Jupiter, to whom there are but twenty-one inscring all told, 
is equated uniformly with Celtic divinities of obscure character.

Only a single goddess, Minerva, is named in Cæsar's list and, though her name occurs in a great number of inscriptions, in but three of them is she identified with a Gaulish divinity. The reason of this is that in the Celtic pantheon there seems to have been hardly any independent female divinity; the Celtic gods are mostly all male and, when occasionally the divinty is female, she is almost invariably the associate (wife, mother or sister), or duplicate, of a male god. Thus the female counterpart of the Celtic Mars is a weird being named Cathabodua, no doubt identical with the Irish war-fury Bodh Catha of the Tain Bó. The Bodh Catha is, in her turn, identical with the Baidhb or Banshee of modern Irish superstition. In the Cuchullain, or Red Branch Tales, this Bodh Catha is found accompanied by three other females, cruel and bloodly as herself, scil:-Macha, Morrigu and Neman, who may indeed be, and very probably are, merely repetitions of herself. It is curious to note, in passing, that in Neman we have another link between Irish and Continental-Celtic paganism; according to the inscriptions Neman was a war-goddess of Eastern Gaul.

More than one ancient authority has made comment on the lively religious sense of the Celts-in marked contrast to the rationalism of their conquerors. To the Celt the future life was no hazy and indefinite 


\section{PREHISTORIC IRELAND}

possibility, but an existence as clear-cut and real as the present. On the occasion of funerals-so Roman writers say-the Gauls threw on the funeral pyre letters addressed to the dead. Moreover, it was no uncommon thing to lend money to the living on security that the debt should be repaid in the world to come. 
- 



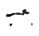

$\because \quad$ twe

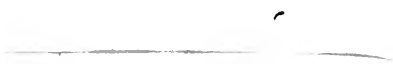


